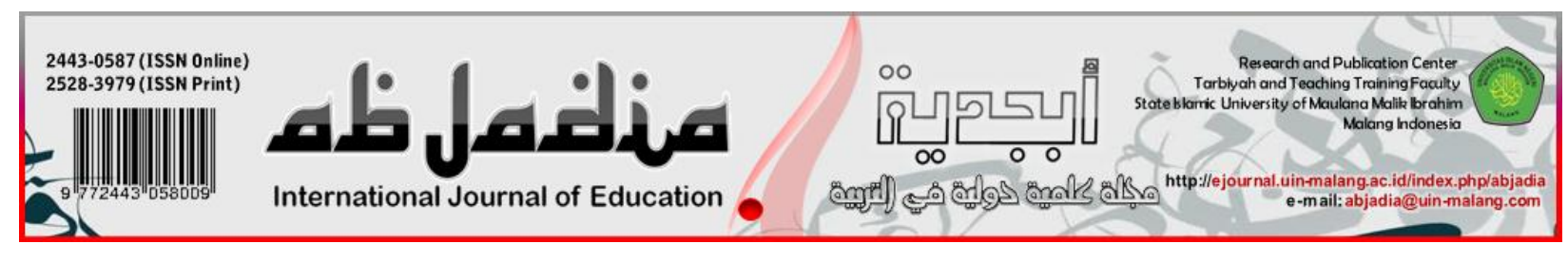

\title{
EVALUATION OF ARABIC LANGUAGE TEXTBOOKS AT UIN SYARIF HIDAYATULLAH JAKARTA
}

\author{
Ahmad Royani ${ }^{1}$, Mukhshon Nawawi $^{2}$, Maswani $^{3}$ \\ 1,2,3 UIN Syarif Hidayatullah Jakarta, Indonesia
}

Article History:
Received : 02-01-2020
Revised : 15-06-2020
Accepted : 17-06-2020
Published : 30-06-2020

Keywords:

Evaluation, Arabic Language Textbooks, Qawaid, Teaching

\section{*Correspondence Address:}

ahmadroyani@uinjkt.ac.id

mukhshonnawawi@uinjkt.ac.id

maswani@uinjkt.ac.id

\begin{abstract}
This research was conducted with the aim of describing the level of compatibility of Arabic language textbooks at UIN Syarif Hidayatullah Jakarta with the general purpose of learning Arabic. This research is a descriptive and non-interactive study. The research method used is the content analysis, because in this study the contents of the textbooks in Arabic was analyzed The results of the study show that in general the books evaluated have been good and decent enough to be used as book dars, except that there needs to be an adjustment in terms of material content. In terms of the completeness, breadth and depth of the material, it appears that the book al-arabiyyah bi annamadziz, al-arabiyyah li tullabil jamiah, and the Arabic language of the Quran, make Arabic material complete, detailed, and profound which is gradually adjusted to the level of marhalah. In terms of material accuracy, these books contain grammatical and accurate terms In terms of the latest material, the book a al-arabiyyah bi annamadziz is considered not up-to-date.
\end{abstract}

\section{C) Introduction}

Learning Arabic at UIN Syarif Hidayatullah Jakarta is directed to develop abilities and foster positive attitudes towards Arabic both receptive and productive. Receptive ability in the sense of the ability to understand the speech of others and understand reading. While the productive ability is the ability to use Arabic as a communication tool both verbally and in writing. Thus, the orientation of Arabic teaching at UIN Syarif Hidayatullah must be directed to the mastery of four Arabic language skills, listening skills (al-istima'), speaking (al-kalam), reading (al-qira'ah), and writing (al-kitabah).

So that the objectives of learning Arabic at Syarif Hidayatullah State Islamic University can be realized, the Arabic language lecturers as the executors of the learning are expected to be able to design and develop teaching materials that are in accordance with these goals and orientations and apply them in learning Arabic. Even if lecturers cannot develop their own teaching materials, they can at least choose available books that meet the qualifications and eligibility, both in terms of the substance of the material, as well as from the organizing techniques. Because, the Arabic learning objectives that have been set will be difficult to achieve, if one of the learning 
components, namely daras books, does not meet the eligibility requirements of an Arabic language book, especially from the point of view of the substance of the material. The learning materials or daras books have a large contribution to make Arabic language learning strategies. Because The daras books also can raise the motivation in student learning.

The variability of books from Arabic courses used by lecturers at UIN Syarif Hidayatullah Jakarta also seems to indicate that lecturers do not yet have the same standards and parameters in choosing Arabic books or may be because the lecturers do not fully understand the size or standard the feasibility of a book from an Arabic course in terms of the selection of material, as well as the organization or presentation. Thus, an evaluation of the books of the subject is needed so that Arabic language lecturers have adequate information about books from Arabic language courses that are appropriate and can lead students to achieve the expected competencies.

Starting from this condition, the writer felt the need to conduct a review of the books from the Arabic language lecturers. The extent to which the Arabic language books are in accordance with the objectives and learning needs of Arabic. To answer this question, it is necessary to conduct an analysis to provide an assessment of various books from Arabic used today with reference to theories relating to the preparation and development of Arabic textbooks for non-Arabs.

Hussein and Ibrahim (2013) conduct the study of setting a standardized criteria, in a form of checklist, for evaluating the textbooks used for teaching Arabic as a Foreign Language (AFL)/ or Arabic as a Second Language(ASL). The checklist suggested and developed by the researchers, they called it (Criteria1) checklist. The targeted lecturers and experts(subjects) have been asked to classify and range each criterion in a scale from 'not important', 'important', to 'very important'. Criteria 1 Checklist is composed of two main groups; the first group includes the general characteristics of the good textbook. The second group is composed of two subgroups; the first one is related to the form of the textbook, the second subgroup is related to the content of it.

Ruth Wilson etall conduct an evaluation of three electronic textbooks on the Web, which focused on assessing how appearance and design can affect users' sense of engagement and directness with the material. The EBONI Project's methodology for evaluating electronic textbooks is outlined and each experiment is described, together with an analysis of results. Finally, some recommendations for successful design are suggested, based on an analysis of all experimental data. These recommendations underline the main findings of the evaluations: that users want some features of paper books to be preserved in the electronic medium, while also preferring electronic text to be written in a scannable style.

Clifton focuses on printed forms of instructional materials and provides detailed information, including examples, on five types of job performance aids, three types of 
instruction sheets, and two types of modules. Checklists of considerations that affect the quality of finished products are also provided. Job performance aids (JPAs)provide procedural or factual guidance in the performance of tasks. Research shows that JPAs are a cost-effective supplement or alternative to training. They reduce the time needed to master task performance and facilitate the transfer of learning from the training setting to the job.

This research is different from previous studies, namely the textbooks studied and also the evaluation criteria. so the results of this study are different from the results of previous studies in the form of the feasibility of the use of textbooks, the advantages and disadvantages of the textbooks used, as well as the updated contents of the textbooksThe introduction contains the purpose of the study and why the study is conducted. The main section of an article should start with an introductory section which provides more details about the paper's purposes, motivation, research methods and findings. The introduction should be relatively nontechnical, yet clear enough for an informed reader to understand the manuscript's contribution.

\section{$\mathbb{Q}$ Theoretical Support}

Hussein and Ibrahim (2013) conduct the study of setting a standardized criteria, in a form of checklist, for evaluating the textbooks used for teaching Arabic as a Foreign Language (AFL)/ or Arabic as a Second Language(ASL). The checklist suggested and developed by the researchers, they called it (Criteria1) checklist. The targeted lecturers and experts(subjects) have been asked to classify and range each criterion in a scale from 'not important', 'important', to 'very important'. Criteria 1 Checklist is composed of two main groups; the first group includes the general characteristics of the good textbook. The second group is composed of two subgroups; the first one is related to the form of the textbook, the second subgroup is related to the content of it.

Ruth Wilson etall conduct an evaluation of three electronic textbooks on the Web, which focused on assessing how appearance and design can affect users' sense of engagement and directness with the material. The EBONI Project's methodology for evaluating electronic textbooks is outlined and each experiment is described, together with an analysis of results. Finally, some recommendations for successful design are suggested, based on an analysis of all experimental data. These recommendations underline the main findings of the evaluations: that users want some features of paper books to be preserved in the electronic medium, while also preferring electronic text to be written in a scannable style.

Clifton focuses on printed forms of instructional materials and provides detailed information, including examples, on five types of job performance aids, three types of instruction sheets, and two types of modules. Checklists of considerations that affect the quality of finished products are also provided. Job performance aids (JPAs)provide 
procedural or factual guidance in the performance of tasks. Research shows that JPAs are a cost-effective supplement or alternative to training. They reduce the time needed to master task performance and facilitate the transfer of learning from the training setting to the job.

This research is different from previous studies, namely the textbooks studied and also the evaluation criteria. so the results of this study are different from the results of previous studies in the form of the feasibility of the use of textbooks, the advantages and disadvantages of the textbooks used, as well as the updated contents of the textbooksThe introduction contains the purpose of the study and why the study is conducted. The main section of an article should start with an introductory section which provides more details about the paper's purposes, motivation, research methods and findings. The introduction should be relatively nontechnical, yet clear enough for an informed reader to understand the manuscript's contribution.

\section{[Q] Method}

This research is a descriptive study because it aims to describe the appropriateness of the substance and system of organizing book material from Arabic courses at UIN Syarif Hidayatullah Jakarta. This research is included in the category of non-interactive or analytical research, because the source of the research data are books from Arabic courses used by lecturers at UIN Syarif Hidayatullah Jakarta.

There are three Arabic books selected by researchers because they represent each type of book and the year of publication and the number of uses, namely the book AlArabiyyah li Tullab al-Jamiah by Chatibul Umam et al consisting of volumes 1, 2 and 3; the book Al-Arabiyyah bi al-Namazij by A.R. Partosentono et al consisting of volumes 1 to 6; Arabic book Qurani by H.D. Hidayat volumes 1, 2, and 3. The research method used is content analysis. The research instrument used was in the form of indicators of the appropriateness of the substance and presentation of the material both made by the experts composing the daras book and determined by the BSNP of the Republic of Indonesia.

Data is analyzed carefully and thoroughly, then processed and given an interpretation of the quality of the feasibility of the book both in terms of content and presentation.

\section{Result}

There are several profiles that will be presented: (1) general characteristics of daras books; (2) general purpose of writing books and book objectives; and (3) language skills developed in the book. The results presented in Table 1, 2, and 3. 
Table 1. General characteristics of daras books

\begin{tabular}{|c|c|c|c|c|c|c|}
\hline $\begin{array}{l}\text { Book } \\
\text { Name }\end{array}$ & Writer & Volume & $\begin{array}{c}\text { The systematic of } \\
\text { the book }\end{array}$ & Lessons & Approach & $\begin{array}{l}\text { Starting } \\
\text { Publish }\end{array}$ \\
\hline$A B N$ & 1 & $\begin{array}{l}\text { Seven (1-4 for } \\
\text { basic, } 5-6 \text { for } \\
\text { intermediate, } \\
7 \text { for advance) }\end{array}$ & $\begin{array}{l}\text { Covers, preface, } \\
\text { introduction, } \\
\text { teacher's } \\
\text { instructions, table } \\
\text { of contents, } \\
\text { transliteration, } \\
\text { discussion, } \\
\text { dictionary }\end{array}$ & $\begin{array}{l}\text { 8-13 } \\
\text { Containts of sentence pattern, } \\
\text { qawaid, tamrinat, } \\
\text { muhadatsah/muthalaah,mahfuzat }\end{array}$ & $\begin{array}{l}\text { all-in-one } \\
\text { system } \\
\text { with } \\
\text { sentence } \\
\text { patterns in } \\
\text { each } \\
\text { chapter }\end{array}$ & 1976 \\
\hline ALJ & $\begin{array}{c}4 \\
\text { (teams) }\end{array}$ & $\begin{array}{l}\text { Three (basic, } \\
\text { intermediate, } \\
\text { advance level) }\end{array}$ & $\begin{array}{l}\text { Covers, preface, } \\
\text { introduction, } \\
\text { teacher's } \\
\text { instructions, table } \\
\text { of contents, } \\
\text { discussion, } \\
\text { dictionary }\end{array}$ & $\begin{array}{l}7 \\
\text { Containts of reading text } 40-50 \\
\text { lines, vocabs, isti'ab, } \\
\text { mulahazah, qawaid,tamrinat }\end{array}$ & $\begin{array}{l}\text { all-in-one } \\
\text { system } \\
\text { with } \\
\text { reading } \\
\text { text }\end{array}$ & $\begin{array}{l}2000 \\
\text { One } \\
\text { revision } \\
\text { in } 2010\end{array}$ \\
\hline BAQ & 1 & $\begin{array}{l}\text { four (basic, } \\
\text { intermediate, } \\
\text { advance level) }\end{array}$ & $\begin{array}{l}\text { Covers, preface, } \\
\text { introduction, } \\
\text { teacher's } \\
\text { instructions, table } \\
\text { of contents, } \\
\text { discussion, } \\
\text { dictionary }\end{array}$ & $\begin{array}{l}12 \\
\text { Containts of main text tanmiyat } \\
\text { mufrodat qawaid tamrinat }\end{array}$ & $\begin{array}{l}\text { Ibadah, } \\
\text { serap, } \\
\text { sharf. } \\
\text { pantas }\end{array}$ & $\begin{array}{l}1999 \\
\text { One } \\
\text { revision } \\
\text { in } 2010\end{array}$ \\
\hline
\end{tabular}

Based on table 1 showed that al-'Arabiyyah bi al-Namazij book (ABN) consists of seven volumes. first, second, third, and fourth volumes are used for the basic level. the fifth and sixth volumes are used for the intermediate level, and the seventh volume is used for the advanced level. The focus of this book is on sentence pattern. While AlArabiyyah li tullab al-Jamiah book (ALJ) consists of three volumes. first, volumes are used for the basic level. the second volumes are used for the intermediate level, while the third volume is used for the advanced level. The focus of this book is on reading text. And Qurani Arabic language book (BAQ) consists of four volumes. first, volumes are used for the basic level. the second volumes are used for the intermediate level, while the third and the fourth volume is used for the advanced level. The focus on reading about Islam and the understanding of Quran.

Table 2. General purpose of writing books and book objectives

\begin{tabular}{clll}
\hline Book Name & \multicolumn{1}{c}{ Orientation } & \multicolumn{1}{c}{ Aims } & Objectives \\
\hline ABN & Language level & $\begin{array}{l}\text { students can master Arabic } \\
\text { sentence patterns) }\end{array}$ & General Department Student \\
\hline ALJ & MKU/SKS & $\begin{array}{l}\text { Students can understand Islamic } \\
\text { religious sciences written in Arabic }\end{array}$ & Islamic Department Student \\
\hline \multirow{3}{*}{ BAQ } & $\begin{array}{l}\text { Pantas } \\
\text { (limited }\end{array}$ & $\begin{array}{l}\text { Student can learn Arabic to } \\
\text { understand Popular Koran Verses, } \\
\text { Readings and Prayers in Worship, } \\
\text { understanding) }\end{array}$ & $\begin{array}{l}\text { Islamic or General Department } \\
\text { Student }\end{array}$ \\
\hline
\end{tabular}

Tabel 2 showed the orientation of ABN book is for language level, ALJ is for MKU/SKS, anda BAQ is for Pantas. The aims of ABN book is for mastering Arabic sentence, ALJ is for understanding Islamic religious sciences, and BAQ is for understanding popular Koran verses. The objectives of $\mathrm{ABN}$ book is for general department student, ALJ is for Islamic department student, and BAQ is for Islamic or 
general department student.

Table 3. Language skill develoved in the book

\begin{tabular}{cll}
\hline Book Name & \multicolumn{1}{c}{ Approach } & Language Skill \\
\hline ABN & all-in-one system & Integrated \\
\hline ALJ & all-in-one system & Integrated \\
\hline \multirow{2}{*}{ BAQ } & $\begin{array}{l}\text { Pantas } \\
\text { (limited understanding) }\end{array}$ & $\begin{array}{l}\text { Comprehension } \\
\text { skill }\end{array}$ \\
\hline
\end{tabular}

Tabel 3 showed the language skill teached as integrated, not only teaches one language proficiency, but all aspects of language are taught in an integrated manner. As for the themes of the reading material does not contain specific themes such as Islamic, social or educational, but prefers loose sentences that are tailored to the sentence patterns that will be taught, differ from BAQ book that choose certain themes that are focused on a particular scientific field starting from the first volume.

\section{¡imiscussion}

The material compatibility with competency standards, al-arabiyyah bi al-namazij book is proper and appropriate to be used as a book from Arabic, because the material presented is in accordance with the competency standard, which contains the Arabic sentence structure starting from simple sentences. Al-arabiyyah li tullab al-jamiah book is also feasible and appropriate to be used as a book from Arabic, because the material presented is in accordance with the competency standard, which contains an Arabic sentence structure containing religious themes. While Qurani Arabic language book is also feasible and appropriate to be used as a book from Arabic, because the material presented is in accordance with the competency standard, which contains an Arabic sentence structure containing religious themes.

In general the language skills developed by these three books fulfill the objectives of learning Arabic at UIN Syarif Hidayatullah Jakarta. only for the Arabic quran book focuses on the skills to understand the reading text only, in contrast to the book alarabiyyah bi annamazij and al-arabiyyah li tullab jamiah is focused on reading skills.

For the breadth and depth of material, al-arabiyyah bi al-namazij's book has a good depth and breadth of material, for example the themes of mubtada and khabar alone are discussed in the first volume. The ABN book presents Arabic language material with complete, detailed, and in depth which is gradually adjusted to its level.

The existing Daras books have the accuracy of grammar and also the terms used. in terms of pictures, the Arabic quran book has advantages over the other two books. in terms of material up-to-date, ALJ and BAQ book are considered up to date, but ABN s book is considered to be less up to date. In general, the three books are in accordance with the developing themes. contains text that contains Islamic studies. 


\section{Conclusion}

Based on the results and discussion, concluded that the three Arabic books used at UIN Syarif Hidayatullah are still appropriate. Teachers can use and choose which book to use by adjusting the books with the aim of teaching Arabic, student background, number of available credits, and equipping books with enrichment, glossary, indexes, pictures and illustrations.

\section{Bibliography}

Abu Bakar, Yusuf al-Khalifah. (2002). Manhaj Ta'lim Al-Lugah Al-Arabiyyah Li Al-Ta'lim Al-Asasi Fi Duwal Al-Sahil Al-Ifriqiy. ISESCO: Rabat.

Ainin, Moch. (2007). Metodologi Penelitian Bahasa Arab. Pasuruan: Hilal Pustaka.

Al-Fauzan, Abdul Rahman Ibn Ibrahim. (2007). I'dad Mawad Ta'lim Al-Lughoh Al'Arabiyyah Li Ghairi Al-Nathiqina Biha. Riyadh: Jami'ah Malik Saud.

Al-Ghali, Nashir Abdullah; Abdul Hamid Abdullah. Usus I'dad al-Kutub al-Ta'liiyyah lighairi al-Nathiqina bi al-'Arabiyyah. Dar al-I'tishom.

Al-Naqah, Mahmud Kamil; Rusydi Ahmad Thu'aimah. (1983). Al-Kitab Al-Asasiy Li Ta'lim Al-Lughah Al-Arabiyyah Li Al-Nathiqiina Bi Al-Lughat Al-Ukhra. Makkah alMukarramah: Jamiat Ummu al-Qura.

Gay, L.R. (1992). Educational Research: Competencies for Analysis and Application. New York: Macmillian Publishing Company, Fourth Edition.

Hamid, M. Abdul, (2002). Tanmiyat Al-Kitab Al-Ta'limiy Fi Madati Al-Qawaid AlNahwiyyah Li Al-Jamiat Ai-Islamiyyah Al-Indunisiyyah Al-Suudaniyyah, Tesis Magister Prodi PBA Pasca Sarjana UIN Malang, tidak diterbitkan.

Hidayatullah, Syarif . (2000). Taqwim Al-Kitab Al-Madrasiy Li-Ta'lim Al-Lughah Al'Arabiyyah Fi Al-Madrasah Al-Tsanawiyah Al-Islamiyah Hasaba Al-Manhaj Al-Ta'limi Li Sanati 1994 Miladiyyah, Tesis Magister Program Pascasarjana UIN Malang, tidak diterbitkan.

Nunan, David (1992). Research Methods in Language Learning. USA, Cambridge: University Press.

Nuruddin, Amin. (2001). Al-'Ittila' Ila Mawad Al-Hiwar Fi Al-Kitab Al-Kitab Al-Madrasiy Li Al-Madaris Al-Tsanawiyah Al Islamiyyah. Tesis Magister Program Pascasarjana, UIN Malang Prodi PBA, tidak diterbitkan.

Permenag RI No. 2 tahun 2008. (2008). Standar Kompetensi Lulusan dan Standar Isi Pelajaran PAI dan bahasa Arab di Madrasah. Jakarta. 
Richards, Jack C. Curriculum Development in Language Teaching. Edisi berbahasa Arab: Tathwir Manahij Ta'lim al-Lughah, ter. Nashir ibn Abdullah ibn Ghali dan Shalih ibn Nashir al-Shuwairh, www. Pdffactory. Com.

Syamsudi AR; Vismaia Damaianti. (2006). Metode Penelitian Pendidikan Bahasa. Bandung: Remaja Rosdakarya.

Thua'imah, Rusydi Ahmad. (1989). Ta'lim Al-Lughah Al-'Arabiyyah Li Ghair Al-Nathiqina Biha: Manahijuhu Wa Asalibuhu. ISESCO, Rabat.

Unaizi, Yusuf dkk. (1999). Manahij Al-Bahts Al-Tarbawiy: Baina Al-Nazhariyyat Wa AlTathbiq. Kuwait: Maktabah al-Falah.

Yunus, Fathi Ali; Muhammad Abdur Rauf. (2003). Al-Marji' Fi Ta'lim Al-Lughah Al'Arabiyyah Li Al-Ajanib: Mi Al-Nadzariyyat Ila Al-Tathbiq. Kairo: Maktabah Wahbah.

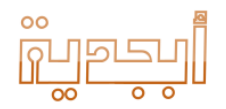

